\title{
Research on the Construction of Practical Teaching System of Art Design Major in Universities and Colleges
}

\author{
Wei Geng \\ Changchun Sci-Tech University, Changchun, 130600, China
}

Keywords: Practical teaching system, Art design major, Practical courses

\begin{abstract}
Practical teaching is a necessary component of the talents cultivation of art design major in universities and colleges. It plays an important role in the improvement of students' theoretical knowledge, the training of professional skills and the enhancement of the ability to solve practical problems. The paper analyses the principles and strategies of the construction of practical teaching system of art design major in universities and colleges to provide some references for the relevant researchers.
\end{abstract}

\section{Introduction}

As a comprehensive subject, art design can not only train students' creative ability in art and design, but also expand their knowledge in social, scientific and other aspects to improve their ability to solve practical problems. In the classroom, the students to master cutting-edge design through the system of the theory of knowledge, ideas and creation of a program and then around the teachers given, finally completed the work, but this is just to stay in the foundation stage of education, from conception to works eventually become products also need to go through the inspection, this requires the designer from the user perspective, follow the principle of people-oriented design concepts will be applied to the social production and life, scientific and rational analysis of the problems encountered in the production and living, understand the needs of the community, to find out the problem-solving methods and ways of exercises, and constantly improve and verify. Only in this way can we test whether the students have grasped the basic principles of design and whether they have acquired the necessary skills in designing. Therefore, practice teaching is an important aspect of art design teaching, and the effect of practical teaching directly affects the cultivation of students' practical ability, and ultimately affects the realization of the teaching goal of the whole profession. Not only can the art design teaching to teach students some theoretical knowledge and production skills, it must pay attention to the development of the students, pay attention to the market demand, develop the potential of students, stimulate the creativity of students, cultivate students' practical ability. To achieve this goal, practical teaching is an effective method. It can provide students with a unique learning opportunity, and their teaching plans focus on the students' intelligence, ability and practice. It provides a teaching environment to stimulate students' enthusiasm for learning, and to encourage students to find problems, to solve problems in a unique way, and even inventions, and give full play to their potential.

\section{Principles of the Construction of Practical Teaching System of Art Design Major}

Follow Educational Laws. The particularity of practice teaching in art design education determines that students must understand and grasp the essence of design by participating in practical activities to master the skills better. Art design teaching practice can not only expand the theoretical knowledge of students, more can through various forms of practice will further promote the theory, students will learn in the classroom of the single scattered knowledge together, stimulate students' creative thinking, their creativity and performance by leaps and bounds ascension. Practice has 
proved that many art design professional innovation ability from many practical activities, application ability of content rich art design practice can greatly develop talent and creativity in art design specialty. In the process of the construction of practical teaching system, we must strictly follow the law of education and teaching, pay attention to cooperate with each other in the teaching, the scientific and systematic methods, will practice various aspects of teaching activities according to the position and function together, and throughout the whole teaching process. Art and design professional talent cultivation orientation is closely around the target of cultivating practical talents, strengthen the cultivation of students' application ability, the ability to focus on professional training objectives to the actual work and enterprise capability requirements, industry standards for training, emphasizing and satisfy the needs of society, to strengthen the application. Following the cognitive and educational law, using the method of science, system, combined with the characteristics of art and design professional, systematic design of practice teaching system, gradually progressive, pay attention to the practice of mutual connection, cooperation, mutual support and mutual penetration of the principle, to the harmonization between the various elements of practical teaching activities. Avoid all aspects of isolated phenomenon. The coordination of teaching content and practice teaching system runs through the whole process of talent training.

Meet Major Characteristics. The construction of the practice teaching system should first conform to the discipline of the discipline itself and the characteristics of the discipline. Secondly, it should conform to the school's idea of running a school and the orientation of talent training. Practicality and application are the basic attributes of art design specialty. Art design discipline is a dynamic development course, students in the design behavior in the process of repeated training and confirmation, is from knowledge to practice, to understand, to repeatedly practice, so practice teaching system construction with science development and artistic characteristics of the subject itself. In the teaching process of art design in Colleges and universities, the conception of design is one of the most important links. Training for design ideas takes a long time to practice. Art design specialty with the change and development of social progress and economic development, and highly dependent on the market and society, penetrated into all aspects of social life, which requires art and design professionals should not only have knowledge of art and design skills, have advanced design concepts, keen awareness of the market, both can be strong creative skills, and strong communication and coordination ability, therefore, the construction of practice teaching to meet the characteristics of the subject of art design specialty. It needs to be realized through systematic training, and an open school idea must be established. One is to open to the society, so that students can integrate into society through professional practice, and enhance their artistic design skills and qualities in the service society. Two is open to other majors. During discipline development, art design needs to absorb the contents of various subjects, enrich its own structure, strengthen communication and cooperation with other majors, and promote the development of art and design specialty. Carrying out practical teaching can let students understand the change of social demand at the same time, strengthen the design ability continuously, reach the level that practice makes perfect.

Adopt Students-centered Model. The practice of teaching to cultivate students' comprehensive quality and the comprehensive ability of students through investigation, hands-on, thinking, analysis and summary of self-mastery of knowledge ability, encourage students' subjectivity, initiative and creativity into full play. During practice teaching, we should introduce the actual project into the classroom so that the students can realize the market demand and marketing operation in the actual project, adapt themselves to the society and the market in advance, and cultivate the students' ability to start their own businesses. On the cultivation of students' innovation and practical ability of art colleges has become the primary goal of contemporary art and design education, throughout the entire design teaching and personnel training mode, the practice process is the process of implementation of creative thinking, to prove himself a new thinking process is fit for the social reality in the actual operation, stimulate innovation ability through practice. The art practice teaching focuses on cultivating students' innovative spirit and practical ability, provide sufficient time and space for students' autonomous learning and self-development, cultivating students' ability, engaged in art and design work to create works of art and design ability, leading the fashion of social life 
ability, in addition, the practice of Art design teaching should pay attention to their own growth. Including personal knowledge, accomplishment, mind growth. Therefore, the construction of practice teaching system to cultivate talents of art design undergraduate quality and ability as the center, innovation and practice, cultivate self-learning ability of students, training should focus on students' professional skills, we should pay more attention to the students' comprehensive abilities. Schools should be classified and decomposed according to the characteristics of different majors and students, and different teaching methods or patterns will be formed to realize individualized teaching. Bringing entrepreneurial ability into practice teaching content of art design specialty is also the mission entrusted by the times to practice teaching.

\section{Strategies of the Construction of Practical Teaching System of Art Design Major}

Value Practical Courses. The university leaders need to pay more attention to teaching practice, and the art design field needs the talents with strong practical ability. We must attach great importance to the practice of teaching activities, clear art and design of the overall teaching goal, increase the proportion of components and the practice teaching, strengthen students' ability of theory and practice. In addition, colleges and universities should actively create a good atmosphere for teaching, stimulate students' enthusiasm for learning, encourage them to participate in various artistic design practices, and truly enhance the practical ability of art and design talents. Art design specialty should be professional teachers and social workers organized by the college with senior and experienced together according to the new trend of professional development and the development of society and economy, the latest development of science, develop scientific and reasonable training scheme is easy to implement, make full use of the characteristics of the course system of Interdisciplinary advantages under the background of engineering school the increase in share and machinery, materials and other disciplines related professional skills based curriculum, emphasizing the integration of design training and practice teaching of professional education in the deal with the relationship between theory teaching and practice teaching, setting level, and progressive, practical teaching content, perfect teaching system. Led by teachers and students to enterprises and institutions jointly guide students through the professional investigation, market research and other social practice, the process of art and design have a clear understanding, to lay the foundation for future practice. During the arrangement, can meet the requirement of the students' occupation qualification fields will occupation qualification certificate into the curriculum system, to enable students to obtain the corresponding occupation qualification certificate in the school will be able to improve their market competitiveness.

Establish Practical Studios. Studio is in recent years many colleges and universities, art, design, professional use of a more teaching model. The composition of the studio is made up of schools and related enterprises and institutions. The teachers in the studio are composed of professional teachers, professional teachers, designers and engineers of the cooperative units. The students in grade one or two is the completion of teaching plan in all the basic courses in professional compulsory courses in the teaching plan of the studio in three or four grades, while the actual title professional courses combined with practice project learning. During study, there are professional teachers who are responsible for the guidance of relevant theoretical knowledge, and the designer is responsible for the overall project design, follow-up and practical guidance. Professional art and design professional teachers lack knowledge about the market and practice skills, teachers rarely have the opportunity to engage in related work with the actual project, the lack of teachers in the production line of work experience, do not understand the process design and the actual operation, it is difficult to meet the requirements of enterprises of high-quality and high skilled talents. Through the establishment of studio, combining art design theory with engineering practice, and promoting teaching through practice, to achieve the greatest degree of interactive teaching, and fully mobilize the enthusiasm of students. The studio is a teaching place, and has the characteristics of the design company to a certain extent, in the way of teaching is different from the traditional way of teaching, relying on enterprises, the actual project of enterprises and institutions to introduce teaching, practice teaching services, 
project driven teaching mode, the students entered the studio it means entering the enterprise, make teaching practice and occupation students have organic convergence, direct induction of social work ability in the learning process.

Construct Practical Bases. It is the foundation and premise of effective practice teaching to build enough practice bases for art design specialty in colleges and universities. On the one hand, universities can increase with institutions, companies and enterprises cooperation, and actively create a variety of art design professional practice base, to provide sufficient opportunities to practice and places for students majoring in art design; on the other hand, universities should increase the school of art and design professional equipment, resources, venues and other infrastructure investment and create good conditions for students to practice, to provide the necessary resources for teachers to carry out practical courses. Practice base is the extension of classroom teaching, art design and related industries closely, should make full use of the advantageous resources related industries to provide good conditions for students to practice, to continuously enhance the ability of social practice. Enterprises need to use the human resources of colleges and universities to obtain intellectual support, while colleges and universities hope to obtain technical support through cooperation with outside practice units, to realize the basic requirements of practical teaching. Enterprises and universities have hope that through cooperation to achieve maximum benefits, but because enterprises in practice to accept students need to provide internship places and provide corresponding guidance personnel, added a lot of burden, also on the production and operation to produce influence, so the normal business, to enable enterprises to see students to the enterprise practice can create economic benefits for them. It is possible to select influential design companies and sign practice bases and cooperation agreements. Schools and employers between targeted delivery, excellent results of the graduates, not only to solve part of the employment of students, but also for the next graduate to create a better practice environment.

\section{Conclusion}

The smooth implementation of the practical teaching is of great significance for promoting the teaching level of art and design major in colleges and universities. In the process of improving and perfecting the practice teaching of art and design specialty, colleges and universities should follow the pace of the times and grasp the new development trend of art and design industry according to the specific situation of local economic development. Colleges and universities further enhance the students' practical ability, so that graduates of art major can adapt themselves to the society as soon as possible.

\section{References}

[1] Wang Yangjun, Luo Yong. On Integration Strategies with Financing Warehouse and Distribution Services for Express Enterprises [J]. Journal of Guangxi Science \& Technology Normal University, 2016, 31(6): 139-141+120.

[2] Wu Xingkuan, Wang Gang, Wang Shuangquan, et al. Construction of Evaluation Index System of Practical Courses for Art Design Major in Colleges and Universities [J]. Design Research, 2016, 2(6): 104-107.

[3] Yang Jie. On the Practice Teaching of Art Design Majors [J]. Journal of Hainan Normal University (Social Sciences), 2017, 30(4): 90-94.

[4] Gao Yong. Research on Innovative Practice-based Teaching Modes of Art Design in Higher Education [J]. Education Modernization, 2016(2): 14-16. 